\title{
PENNSTATE
}

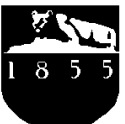

\section{Deep Desulfurization of Diesel Fuels by a Novel Integrated Approach}

\author{
Semiannual Technical Report \\ For the Period \\ March 1 - August 31, 2001 \\ Grant Number: DE-FG26-00NT40821 \\ Xiaoliang Ma, Lu Sun and Chunshan Song* \\ Clean Fuels and Catalysis Program, The Energy Institute, and \\ Department of Energy \& Geo-Environmental Engineering \\ Pennsylvania State University \\ 209 Academic Projects Building, University Park, PA 16802 \\ * E- Mail: csong@psu.edu / Tel: 814-863-4466 / Fax: 814-865-3248 \\ Submitted to \\ AAD Document Control Center, M/S 921-107 \\ National Energy Technology Center \\ US Department of Energy \\ P. O. Box 10940 \\ Pittsburgh, PA 15236
}

September 2001 


\section{DISCLAIMER}

This report was prepared as an account of work sponsored by the United States Government. Neither the United States Government nor any agency thereof, nor any of their employees, makes any warranty express or implied, or assumes any legal liability or responsibility for the accuracy, completeness, or usefulness of any information, apparatus, product, or process disclosed, or represents that its use would not infringe privately owned rights. Reference herein to any specific commercial product, process or service by trade name, mark manufacturer, or otherwise, does not necessarily constitute or imply its endorsement, recommendation, or favoring by the United States Government or any agency thereof. The views and opinions of authors expressed herein do not necessarily state or reflect those of the United States Government or any agency thereof. 


\section{Abstract}

Due to the increasingly stricter regulations for deep reduction of fuel sulfur content, development of new deep desulfurization processes for liquid transport fuels has become one of the major challenges to the refining industry and to the production of hydrocarbon fuels for fuel cell applications. The sulfur compounds in the current transport fuels corresponding to the S level of 350-500 ppm account for only about 0.12-0.25 wt \% of the fuel. The conventional hydrotreating approaches will need to increase catalyst bed volume at high-temperature and high-pressure conditions for treating $100 \%$ of the whole fuel in order to convert the fuel mass of less than $0.25 \mathrm{wt} \%$. In the present study, we are exploring a novel adsorption process for desulfurization at low temperatures, which can effectively reduce the sulfur content in gasoline, jet fuel and diesel fuel at low investment and operating cost to meet the needs for ultra-clean transportation fuels and for fuel cell applications.

Some adsorbents were prepared in this study for selective adsorption of sulfur compounds in the fuels. The adsorption experiments were conducted by using a model fuel and real fuels. The results show that the adsorbent (A-1) with a transition metal compound has a significant selectivity for sulfur compounds with a saturated adsorption capacity of $\sim 0.12 \mathrm{~mol}$ of sulfur compounds per mol of the metal compound. Most sulfur compounds existing in the current commercial gasoline, jet fuel and diesel fuel can be removed by the adsorption using adsorbent $\mathrm{A}-1$. On the basis of the preliminary results, a novel concept for integrated process for deep desulfurization of liquid hydrocarbons was proposed. 


\section{Table of Contents}

i Title Page*

ii Disclaimer*

1) Abstract*

2) Table of Contents*

3) List of Graphical Materials*

4) Introduction*

5) Executive Summary*

6) Experimental*

7) Results and Discussion*

8) Conclusion*

9) Acknowledgments

10) References*

* Contents and Sequence Specified in the DOE "Technical Report Submission Instructions". 


\section{List of Graphical Materials}

Figure 1. GC-FPD chromatograms of commercial gasoline, jet fuel and diesel

Figure 2. GC-FPD chromatograms of gasoline and treated gasoline

Figure 3. GC-FPD chromatograms of diesel and treated diesel

Figure 4. The proposed adsorption process for ultra-deep desulfurization 


\section{Introduction}

In order to reduce the sulfur content in transport fuels for environmental protection purpose, US Environmental Protection Agency has issued regulations that will require the refineries to reduce the sulfur content of gasoline from a current average of $300 \mathrm{ppm}$ to 30 ppm by 2006, and the sulfur content of highway diesel fuel from a current limit of 500 ppm to 15 ppm by 2006 .

In terms of technology availability, the sulfur content in gasoline can be reduced to less than $30 \mathrm{ppm}$ by current hydrotreating processes. The major problem is that the current hydrotreating technology results in high hydrogen consumption and significant reduction of octane number due to olefin saturation. ${ }^{1}$ For diesel fuel, the current hydrotreating technology is difficult to reduce the sulfur content to less than $50 \mathrm{ppm}$, because the remaining sulfur compounds in current diesel fuel are the refractory sulfur compounds..$^{2-4}$ These refractory sulfur compounds are the alkyl dibenzothiophenes with one or two alkyl groups at 4- and 6-positions, which strongly inhibit hydrodesulfurization of the compounds. ${ }^{5-7}$ The kinetic study shows that in order to reduce the sulfur content of the diesel fuel from $350 \mathrm{ppm}$ to less than $50 \mathrm{ppm}$ using the current hydrotreating technology, even with catalysis twice as active as current commercial catalysts, the reactor volume must be at least a couple of times larger than those currently used in refineries. ${ }^{2,3}$ As is well known, the increase in volume of the high-temperature and highpressure reactor is very expensive and the increase of catalyst activity by even $50 \%$ over existing hydrotreating catalysts is hard as the existing hydrotreating catalysts have been developed and optimized over the pass 50 years.

The regulation for ultra-low sulfur fuel is motivated in part by the need for using the new emission-control technologies that are sensitive to sulfur. On the other hand, ultraclean fuel is also needed for use with a fuel cell system. ${ }^{8}$ Fuel cell is one of the most promising and convenient energy conversion devices for generating electricity for both mobile vehicles and stationary power plants including residential applications. For the 
automotive fuel cells and military fuel cells, liquid hydrocarbons (gasoline, kerosene, jet fuel or diesel) are ideal fuels due to their higher energy density, ready availability, and safety for transportation and storage. However, the liquid hydrocarbons usually contain certain sulfur compounds that are poisonous to both the shift catalysts in hydrocarbon fuel process and the electrode catalysts in fuel cell process. Thus, the sulfur compounds in the liquid hydrocarbons need to be reduced to less than $0.1 \mathrm{ppm}$. Apparently, the current hydrotreating technology is hard to meet such a need.

Consequently, development of new deep desulfurization processes for liquid transport fuels becomes one of the major challenges to the refining industry and to the fuels for fuel cell application.

The sulfur compounds in the current transport fuels corresponding to the $\mathrm{S}$ level of $350 \mathrm{ppm}$ account for only about $0.12-0.25 \mathrm{wt} \%$ of the fuel. The conventional hydrotreating approaches will need to increase catalyst bed volume at high-temperature and high-pressure conditions for treating $100 \%$ of the whole fuel in order to convert the fuel mass of less than $0.25 \mathrm{wt} \%$. In the present approaches we attempted to develop a novel adsorption process, which can effectively reduce the sulfur content in gasoline, jet fuel and diesel fuel at low investment and operating cost to meet the needs for ultra-clean transportation fuels and for fuel cell applications.

\section{Executive Summary}

- Sulfur compounds in some commercial liquid-hydrocarbon fuels, including gasoline, jet fuel and diesel fuel, were identified by using GC-FPD and GCPFPD.

- Some adsorbents were prepared in our laboratory for the selective adsorption of sulfur compounds from the liquid hydrocarbon fuels. 
- The adsorption experiments were conducted by using the prepared adsorbents to compare the selectivities of sulfur compounds and aromatic compounds coexisting in the fuels. The capacity of the adsorbents was determined.

- On the basis of the present study, a novel process for deep desulfurization of liquid hydrocarbons, which combines a selective adsorption process of the sulfur compounds and a hydrodesulfurization process of the concentrated sulfur fraction, was proposed. The major potential advantages of the proposed process were studied by comparison with the conventional hydrodesulfurization process.

\section{Experimental}

The diesel fuel and gasoline used in this study are the commercial products from gasoline stations. The jet fuel is JP-8, provided by Air Force Research Laboratory. A model diesel with 304 ppmw sulfur from dibenzothiophene and 284 ppmw sulfur from 4,6-dimethyldibenzothiophene was used to determine the capacity of the adsorbent. The composition of the model diesel is listed in Table 1. The adsorbent (A-1) used in this study was prepared by ourselves is a transitional metal compound supported on silica gel with 5.0 wt $\%$ loading of the metal compound. The adsorption experiments were performed at ambient temperature and pressure in a fixed adsorption bed, a glass column with internal diameter of $11 \mathrm{~mm}$ and length of $300 \mathrm{~mm}$. About $5 \mathrm{~g}$ of the prepared adsorbent was filled in the column. The fuels were poured into the glass column and flowed down through the adsorption bed. The sulfur compounds in the fuels and treated fuels were analyzed using GC-FPD and GC-FID with a capillary column.

\section{Results and Discussion}

\subsection{Identification of Sulfur Compounds}

FPD gas chromatograms of the gasoline, jet fuel and diesel fuel are shown in Figure 1. The major sulfur compounds existing in the commercial gasoline are thiophene, 2methylthiophene, 3-methylthiophene, 2,4-dimethylthiophene and benzothiophene. The major sulfur compounds in JP-8 are dimethylthiophenes and trimethylthiophenes with two methyl groups at 2- and 3-positions, respectively. No dibenzothiophenes was 
detected in JP-8. The sulfur compounds in the commercial diesel fuel include alkyl benzothiophenes and alkyl dibenzothiophenes, but the major sulfur compounds are the alkyl dibenzothiophenes with alkyl groups at 4- or/and 6-positions, indicating that the major sulfur compounds remaining in the diesel fuel are the refractory sulfur compounds, which are difficult to be removed by the conventional HDS process.

\subsection{Adsorption}

Desulfurization of the gasoline, jet fuel and diesel fuel by adsorption was preformed at ambient temperature by using adsorbent A-1. Figure 2 shows a comparison of the gasoline feed and the treated gasoline. It is clear that almost no sulfur signal was detected in the treated gasoline, indicating that most of the sulfur compounds in the gasoline were removed by the adsorption. Figure 3 shows a comparison of the diesel feed and the treated diesel. It shows that sulfur compounds, including 4,6-dimethyldibenzothiophene, in the diesel were substantially removed by the adsorption. The desulfurization experiments of the jet fuel by the adsorption give similar results, implying that the adsorbent A-1 is efficient for selectively adsorbing the sulfur compounds in the fuels.

As diesel fuels contain not only sulfur compounds, but also aromatic hydrocarbons at high concentrations in the range of 10-30 wt \%, a major challenge for separating the sulfur compounds from the diesel fuel is to find a adsorbent that selectively adsorbs the sulfur compounds, but does not adsorb (or weakly adsorb) the coexisting aromatic hydrocarbons. The recovery of the adsorbates from the spent adsorbent was performed by elution using a polar organic solvent. A concentrated sulfur fraction was obtained by evaporating the polar organic solvent from the eluate. Analysis of the concentrated sulfur fraction shows that more than $90 \mathrm{wt} \%$ of compounds in the fraction are sulfur compounds, indicating that the adsorbent A-1 has excellent selectivity for adsorbing the sulfur compounds. Our experiments also show that the spent adsorbent can be regenerated by solvent elution followed by removal of the solvent from the adsorbent.

\subsection{A New Deep Desulfurization Process}


On the basis of the present study, we propose a novel process for deep desulfurization of liquid hydrocarbons, which combines a selective adsorption process of the sulfur compounds and a hydrodesulfurization process of the concentrated sulfur fraction, as shown in Figure 4. The sulfur compounds in fuels are first adsorbed on the adsorbent in an adsorber, then, recovered by solvent elution. The spent adsorbent is regenerated via solvent elution followed by removal of the solvent. The eluate is sent to an evaporator to recycle the solvent and to obtain a concentrated sulfur fraction, which account for less than $1 \mathrm{wt} \%$ of the whole fuel. The concentrated sulfur fraction is hydrodesulfurized in a small HDS reactor. Then, the HDS product is blended with the hydrocarbon fraction from the adsorber. This process is quite different from IRVAD process $^{9,10}$ and S Zorb process ${ }^{11}$ in adsorbent, adsorption mechanism and regeneration method. The major potential advantages of the proposed process are 1) adsorption process works at ambient temperature and ambient press; 2) low hydrogen consumption in the process; 3) easy regeneration of the spent adsorbent, 4) low investment and operating cost and 4) little or no octane penalty for gasoline.

\section{Conclusion}

- The major sulfur compounds in the current commercial gasoline, jet fuel and diesel fuel were identified. The major sulfur compounds existing in the gasoline are thiophene and alkylthiophenes. The major sulfur compounds in JP-8 are dimethylthiophenes and trimethylthiophenes with two methyl groups at 2- and 3positions, respectively. The sulfur compounds in the commercial diesel fuel include alkyl benzothiophenes and alkyl dibenzothiophenes, but the major sulfur compounds are the alkyl dibenzothiophenes with alkyl groups at 4- or/and 6-positions, indicating that the remaining sulfur compounds are the refractory sulfur compounds, which are difficult to be removed by the conventional HDS process.

- The prepared adsorbent in this study shows a significant selectivity for sulfur compounds with a saturated adsorption capacity of $\sim 0.12 \mathrm{~mol}$ of sulfur compounds per mol of the metal compound. 
- Most sulfur compounds existing in the current commercial gasoline, jet fuel and diesel fuel can be removed by the adsorption using adsorbent A-1.

- A novel process for deep desulfurization of liquid hydrocarbons was proposed. In comparison with the conventional hydrodesulfurization process, our ultra-deep desulfurization process has some potential advantages: 1. Efficient for ultra-deep desulfurization. 2. Adsorption process is at ambient temperature and ambient pressure, low hydrogen consumption, which leads to low energy consumption, low investment and low operating cost. 3. More efficient for HDS of the refractory sulfur compounds by increasing the concentration of sulfur compounds. 4. Little or no octane penalty for gasoline.

\section{Acknowledgments}

This work was supported by US Department of Energy. Funding was provided by National Energy Technology Laboratory of DOE under UCR Contract DE-FG2600NT40821.

\section{References}

1. P.H. Desal; S. L. Lee; R. J. Jonker; M. De Boer; J. Vrieling; M.S. Sarli. Fuel Reformulation, Nov./Dec. 1994, p. 43-52.

2. X. Ma; Sakanishi,K. Mochida, I. Ind. Eng. Chem. Res. 1994, 33, 218-222.

3. D. D. Wihehurst; Isoda, T.; Mochida, I. Adv. Cat. 1998, 42, 345-471.

4. C. Song. in Chemistry of Diesel Fuels, Song, C.; Hsu, C. S.; Mochida, I. eds. Taylor and Francis, New York, 2000, p. 1.

5. X. Ma; Sakanishi,K.; Isoda, T.; Mochida, I. Energy \& Fuels 1995, 9, 33-37.

6. X. Ma; Sakanishi,K. Mochida, I. Ind. Eng. Chem. Res. 1996, 35, 2487-2494.

7. X. Ma; Sakanishi,K.; Isoda, T.; Mochida, I. in Hydrotreating Technology for Pollution Control, M. L. Occelli, R. Chianelli, eds. Marcel Dekker, 1996, p. 183-195.

8. C. Song. Am. Chem. Soc. Div. Fuel Chem. Prepr., 2001, 46 (1), 8-13.

9. Hydrocarbon Processing, May 1999, p. 39.

10. Irvine, R. L. U.S. Pat. No. 5,730,860, 1998.

11. http://www.szorb.com/sulfur_removal.htm. 2001. 
Table 1. Composition of the model diesel fuel

\begin{tabular}{|c|c|c|}
\hline No. name & $\begin{array}{l}\text { Content } \\
\text { wt } \%\end{array}$ & $\begin{array}{l}\text { S content } \\
\text { wt ppm }\end{array}$ \\
\hline \multicolumn{3}{|l|}{ Sulfur compounds } \\
\hline DBT $(98 \%)$ & 0.175 & 304 \\
\hline 4,6-DMDBT(97\%) & 0.188 & 284 \\
\hline total & & 588 \\
\hline \multicolumn{3}{|l|}{ Unsaturated HC } \\
\hline naphthalene & 0.120 & \\
\hline 2-methylnaphthalene & 0.127 & \\
\hline butylbenzene & 11.6 & \\
\hline 1-octene & 4.7 & \\
\hline \multicolumn{3}{|l|}{ Paraffin } \\
\hline n-Dodecane & 19.6 & \\
\hline Tetradecane & 62.5 & \\
\hline Others & 1.0 & \\
\hline Total & 100.0 & \\
\hline
\end{tabular}




\section{Gasoline}

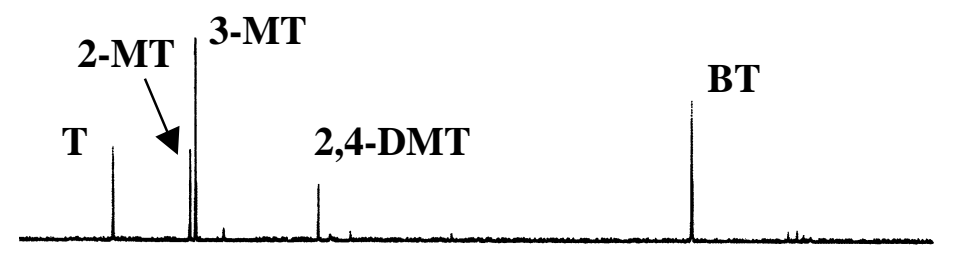

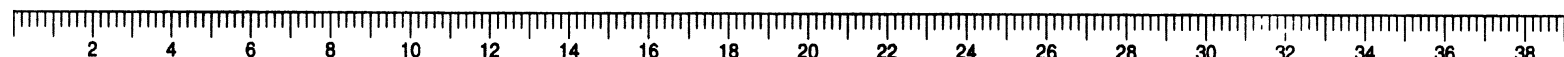
Jet Fuel (JP-8)

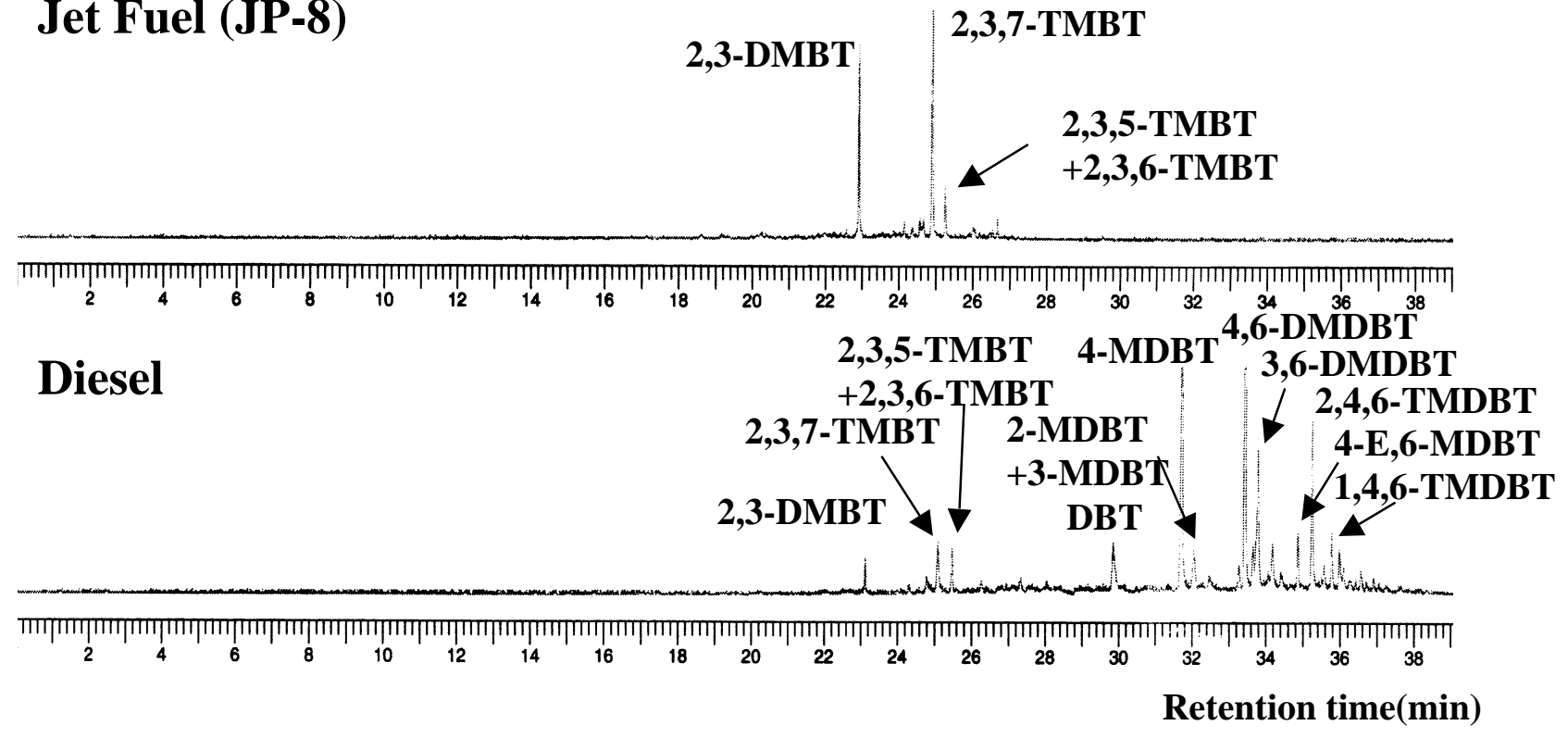

Figure 1. GC-FPD chromatograms of commercial gasoline, jet fuel and diesel 

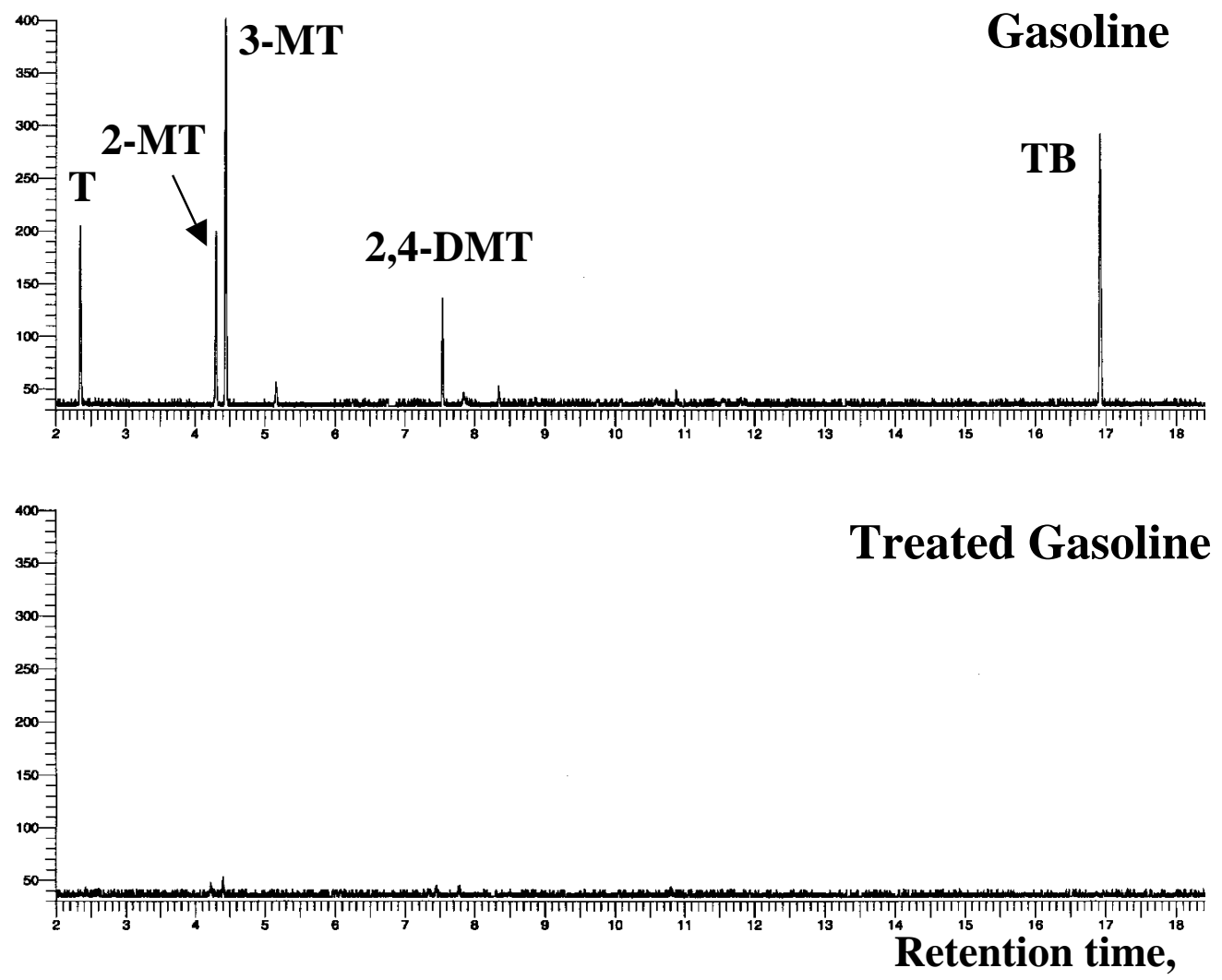

Figure 2. GC-FPD chromatograms of gasoline and treated gasoline 


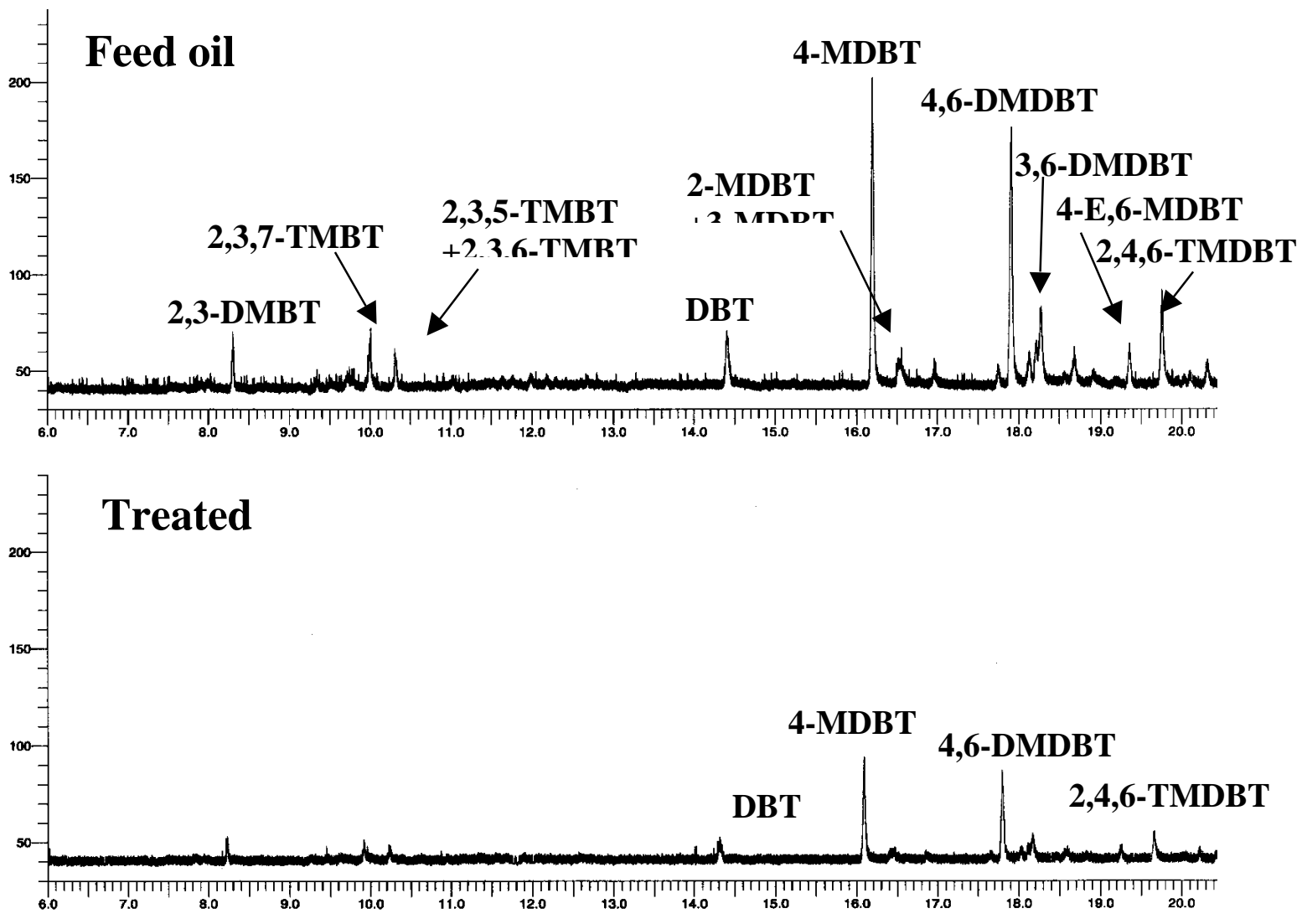

Figure 3. GC-FPD chromatograms of diesel and treated diesel 


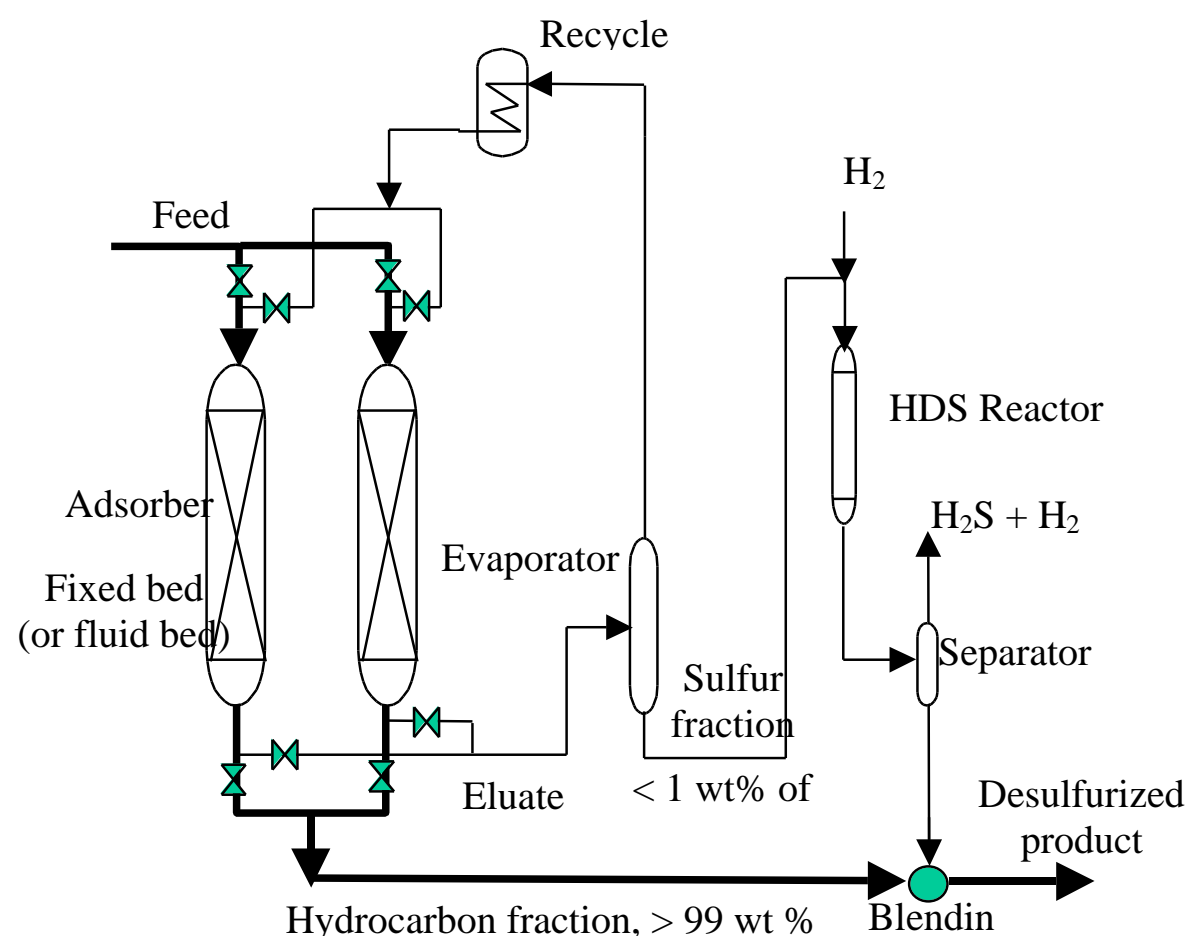

Figure 4. The proposed adsorption process for ultra-deep desulfurization 


\title{
PENNSTATE
}

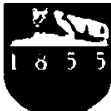

\section{Deep Desulfurization of Diesel Fuels by a Novel Integrated Approach}

\author{
Semiannual Technical Report \\ For the Period \\ September 1, 2000-February 28, 2001 \\ Grant Number: DE-FG26-00NT40821

\begin{abstract}
Xiaoliang Ma, Lu Sun and Chunshan Song*
Clean Fuels and Catalysis Program, The Energy Institute, and

Department of Energy \& Geo-Environmental Engineering

Pennsylvania State University

209 Academic Projects Building, University Park, PA 16802
\end{abstract} \\ * E- Mail: csong@psu.edu / Tel: 814-863-4466 / Fax: 814-865-3248
}

Submitted to

AAD Document Control Center, M/S 921-107

National Energy Technology Center

US Department of Energy

P. O. Box 10940

Pittsburgh, PA 15236

March 2001 


\section{DISCLAIMER}

This report was prepared as an account of work sponsored by the United States Government. Neither the United States Government nor any agency thereof, nor any of their employees, makes any warranty express or implied, or assumes any legal liability or responsibility for the accuracy, completeness, or usefulness of any information, apparatus, product, or process disclosed, or represents that its use would not infringe privately owned rights. Reference herein to any specific commercial product, process or service by trade name, mark manufacturer, or otherwise, does not necessarily constitute or imply its endorsement, recommendation, or favoring by the United States Government or any agency thereof. The views and opinions of authors expressed herein do not necessarily state or reflect those of the United States Government or any agency thereof. 


\section{Abstract}

Due to the increasingly stricter regulations for deep reduction of fuel sulfur content, development of new deep desulfurization processes for liquid transport fuels has become one of the major challenges to the refining industry and to the fuels for fuel cell applications. The sulfur compounds in the current transport fuels corresponding to the $S$ level of $350 \mathrm{ppm}$ account for only about $0.12-0.25 \mathrm{wt} \%$ of the fuel. The conventional hydrotreating approaches will need to increase catalyst bed volume at high-temperature and high-pressure conditions for treating $100 \%$ of the whole fuel in order to convert the fuel mass of less than $0.25 \mathrm{wt} \%$. In the present approaches we attempted to develop a novel adsorption process, which can effectively reduce the sulfur content in gasoline, jet fuel and diesel fuel at low investment and operating cost to meet the needs for ultra-clean transportation fuels and for fuel cell applications. 


\section{Table of Contents*}

i Title Page*

ii Disclaimer*

1. Abstract*

2. Table of Contents*

3. List of Graphical Materials*

4. Introduction

5. Executive Summary*

6. Experimental*

7. Results and Discussion*

8. Conclusion*

9. Acknowledgments

10. References*

* Contents and Sequence Specified in the DOE "Technical Report Submission Instructions". 


\section{List of Graphical Materials}

Figure 1. GC-FPD chromatograms of commercial gasoline, jet fuel and diesel

Figure 2. GC-FPD chromatograms of gasoline and treated gasoline

Figure 3. The proposed adsorption process for ultra-deep desulfurization 


\section{Introduction}

In order to reduce the sulfur content in transport fuels for environmental protection purpose, US Environmental Protection Agency has issued regulations that will require the refineries to reduce the sulfur content of gasoline from a current average of $300 \mathrm{ppm}$ to $30 \mathrm{ppm}$ by 2006 , and the sulfur content of highway diesel fuel from a current limit of 500 ppm to 15 ppm by 2006.

In terms of technology availability, the sulfur content in gasoline can be reduced to less than $30 \mathrm{ppm}$ by current hydrotreating processes. The major problem is that the current hydrotreating technology results in high hydrogen consumption and significant reduction of octane number due to olefin saturation.' For diesel fuel, the current hydrotreating technology is difficult to reduce the sulfur content to less than $50 \mathrm{ppm}$, because the remaining sulfur compounds in current diesel fuel are the refractory sulfur compounds. $^{2-4}$ These refractory sulfur compounds are the alkyl dibenzothiophenes with one or two alkyl groups at 4- and 6-positions, which strongly inhibit hydrodesulfurization of the compounds. ${ }^{5-7}$ The kinetic study shows that in order to reduce the sulfur content of the diesel fuel from $350 \mathrm{ppm}$ to less than $50 \mathrm{ppm}$ using the current hydrotreating technology, even with catalysis twice as active as current commercial catalysts, the reactor volume must be at least a couple of times larger than those currently used in refineries. ${ }^{2,3}$ As is well known, the increase in volume of the high-temperature and highpressure reactor is very expensive and the increase of catalyst activity by even $50 \%$ over existing hydrotreating catalysts is hard as the existing hydrotreating catalysts have been developed and optimized over the pass 50 years.

The regulation for ultra-low sulfur fuel is motivated in part by the need for using the new emission-control technologies that are sensitive to sulfur. On the other hand, ultraclean fuel is also needed for use with a fuel cell system. ${ }^{8}$ Fuel cell is one of the most promising and convenient energy conversion devices for generating electricity for both mobile vehicles and stationary power plants including residential applications. For the automotive fuel cells and military fuel cells, liquid hydrocarbons (gasoline, kerosene, jet fuel or diesel) are ideal fuels due to their higher energy density, ready availability, and safety for transportation and storage. However, the liquid hydrocarbons usually contain 
certain sulfur compounds that are poisonous to both the shift catalysts in hydrocarbon fuel process and the electrode catalysts in fuel cell process. Thus, the sulfur compounds in the liquid hydrocarbons need to be reduced to less than $0.1 \mathrm{ppm}$. Apparently, the current hydrotreating technology is hard to meet such a need.

Consequently, development of new deep desulfurization processes for liquid transport fuels becomes one of the major challenges to the refining industry and to the fuels for fuel cell application.

The sulfur compounds in the current transport fuels corresponding to the $S$ level of $350 \mathrm{ppm}$ account for only about $0.12-0.25$ wt $\%$ of the fuel. The conventional hydrotreating approaches will need to increase catalyst bed volume at high-temperature and high-pressure conditions for treating $100 \%$ of the whole fuel in order to convert the fuel mass of less than $0.25 \mathrm{wt} \%$.

\section{Executive Summary}

In the present approaches we attempted to develop a novel adsorption process by a combination of a selective adsorption process and HDS of the concentrated sulfur compounds, which can effectively reduce the sulfur content in gasoline, jet fuel and diesel fuel at low investment and operating cost to meet the needs for ultra-clean transportation fuels and for fuel cell applications.

\section{Experimental}

The diesel fuel and gasoline used in this study are the commercial products from gasoline stations. The jet fuel is JP-8, provided by Air Force Research Laboratory. The adsorbent (A-1) used in this study was prepared by ourselves. It is a transitional metal compound supported on silica gel with $5.0 \mathrm{wt} \%$ loading of the metal compound. The adsorption experiments were performed at ambient temperature and pressure in a fixed adsorption bed, a glass column with internal diameter of $11 \mathrm{~mm}$ and length of $300 \mathrm{~mm}$. About $10 \mathrm{~g}$ of the prepared adsorbent was filled in the column. The fuels were poured into the glass column and flowed down through the adsorption bed. The sulfur 
compounds in the fuels and treated fuels were analyzed using GC-FPD with a capillary column.

\section{Results and Discussion}

Identification of Sulfur Compounds. FPD gas chromatograms of the gasoline, jet fuel and diesel fuel are shown in Figure 1. The major sulfur compounds existing in the commercial gasoline are thiophene, 2-methylthiophene, 3-methylthiophene, 2,4dimethylthiophene and benzothiophene. The major sulfur compounds in JP-8 are dimethylthiophenes and trimethylthiophenes with two methyl groups at 2- and 3positions, respectively. No dibenzothiophenes was detected in JP-8. The sulfur compounds in the commercial diesel fuel include alkyl benzothiophenes and alkyl dibenzothiophenes, but the major sulfur compounds are the alkyl dibenzothiophenes with alkyl groups at 4- or/and 6-positions, indicating that the major sulfur compounds remaining in the diesel fuel are the refractory sulfur compounds, which are difficult to be removed by the conventional HDS process.

Adsorption. Desulfurization of the gasoline, jet fuel and diesel fuel by adsorption was preformed at ambient temperature by using adsorbent A-1. Figure 2 shows a comparison of the gasoline feed and the treated gasoline. It is clear that almost no sulfur signal was detected in the treated gasoline, indicating that most of the sulfur compounds in the gasoline were removed by the adsorption. The desulfurization experiments of the jet fuel and diesel fuel by the adsorption give similar results, implying that the adsorbent A-1 is efficient for adsorbing the sulfur compounds in the fuels.

As diesel fuels contain not only sulfur compounds, but also aromatic hydrocarbons at high concentrations in the range of $10-30 \mathrm{wt} \%$, a major challenge for separating the sulfur compounds from the diesel fuel is to find a adsorbent that selectively adsorbs the sulfur compounds, but does not adsorb (or weakly adsorb) the coexisting aromatic hydrocarbons. The recovery of the adsorbates from the spent adsorbent was performed by elution using a polar organic solvent. A concentrated sulfur fraction was obtained by evaporating the polar organic solvent from the eluate. Analysis of the concentrated sulfur 
fraction shows that more than $90 \mathrm{wt} \%$ of compounds in the fraction are sulfur compounds, indicating that the adsorbent A-1 has excellent selectivity for adsorbing the sulfur compounds. Our experiments also show that the spent adsorbent can be regenerated by solvent elution followed by removal of the solvent from the adsorbent.

A New Deep Desulfurization Process. On the basis of the present study, we propose a novel process for deep desulfurization of liquid hydrocarbons, which combines a selective adsorption process of the sulfur compounds and a hydrodesulfurization process of the concentrated sulfur fraction, as shown in Figure 3. The sulfur compounds in fuels are first adsorbed on the adsorbent in an adsorber, then, recovered by solvent elution. The spent adsorbent is regenerated via solvent elution followed by removal of the solvent. The eluate is sent to an evaporator to recycle the solvent and to obtain a concentrated sulfur fraction, which account for less than $1 \mathrm{wt} \%$ of the whole fuel. The concentrated sulfur fraction is hydrodesulfurized in a small HDS reactor. Then, the HDS product is blended with the hydrocarbon fraction from the adsorber. This process is quite different from IRVAD process ${ }^{9,10}$ and $S$ Zorb process $^{11}$ in adsorbent, adsorption mechanism and regeneration method. The major potential advantages of the proposed process are 1) adsorption process works at ambient temperature and ambient press; 2) low hydrogen consumption in the process; 3 ) easy regeneration of the spent adsorbent, 4) low investment and operating cost and 4) little or no octane penalty for gasoline.

\section{Conclusions}

The major sulfur compounds remaining in the diesel fuel are the refractory sulfur compounds, which are difficult to be removed by the conventional HDS process. The prepared adsorbent A-1 is efficient for selectively adsorbing the sulfur compounds in the fuels. On the basis of the present study, we propose a novel process for deep desulfurization of liquid hydrocarbons, which combines a selective adsorption process of the sulfur compounds and a hydrodesulfurization process of the concentrated sulfur fraction. 


\section{Acknowledgments}

This work was supported by US Department of Energy. Funding was provided by National Energy Technology Laboratory of DOE under UCR Contract DE-FG2600NT40821.

\section{References}

1. P.H. Desal; S. L. Lee; R. J. Jonker; M. De Boer; J. Vrieling; M.S. Sarli. Fuel Reformulation, Nov./Dec. 1994, p. 43-52.

2. X. Ma; Sakanishi,K. Mochida, I. Ind. Eng. Chem. Res. 1994, 33, 218-222.

3. D. D. Wihehurst; Isoda, T.; Mochida, I. Adv. Cat. 1998, 42, 345-471.

4. C. Song. in Chemistry of Diesel Fuels, Song, C.; Hsu, C. S.; Mochida, I. eds. Taylor and Francis, New York, 2000, p. 1.

5. X. Ma; Sakanishi,K.; Isoda, T.; Mochida, I. Energy \& Fuels 1995, 9, 33-37.

6. X. Ma; Sakanishi,K. Mochida, I. Ind. Eng. Chem. Res. 1996, 35, 2487-2494.

7. X. Ma; Sakanishi,K.; Isoda, T.; Mochida, I. in Hydrotreating Technology for Pollution Control, M. L. Occelli, R. Chianelli, eds. Marcel Dekker, 1996, p. 183-195.

8. C. Song. Am. Chem. Soc. Div. Fuel Chem. Prepr., 2001, 46 (1), 8-13.

9. Hydrocarbon Processing, May 1999, p. 39.

10. Irvine, R. L. U.S. Pat. No. 5,730,860, 1998.

11. http://www.szorb.com/sulfur_removal.htm. 2001. 


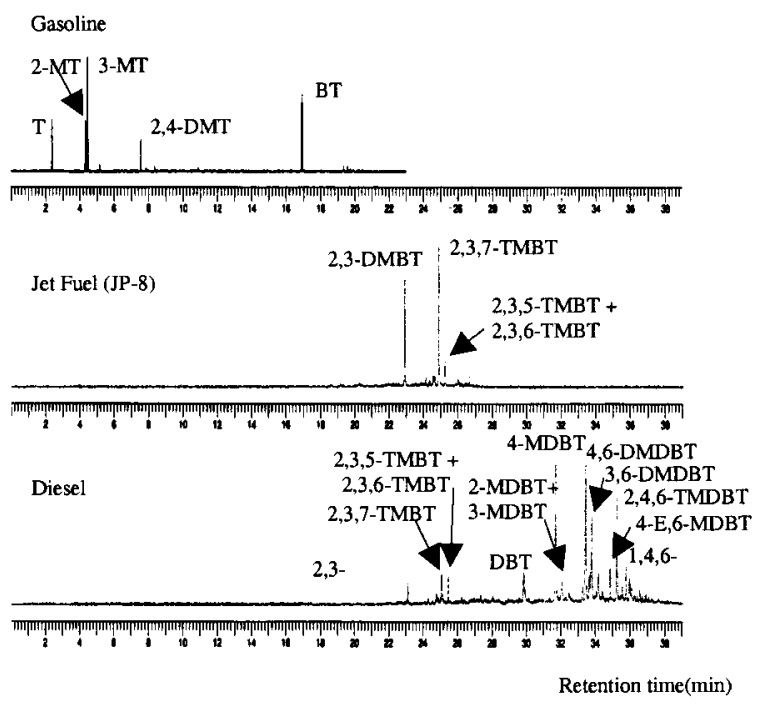

Figure 1. GC-FPD chromatograms of commercial gasoline, jet fuel and diesel
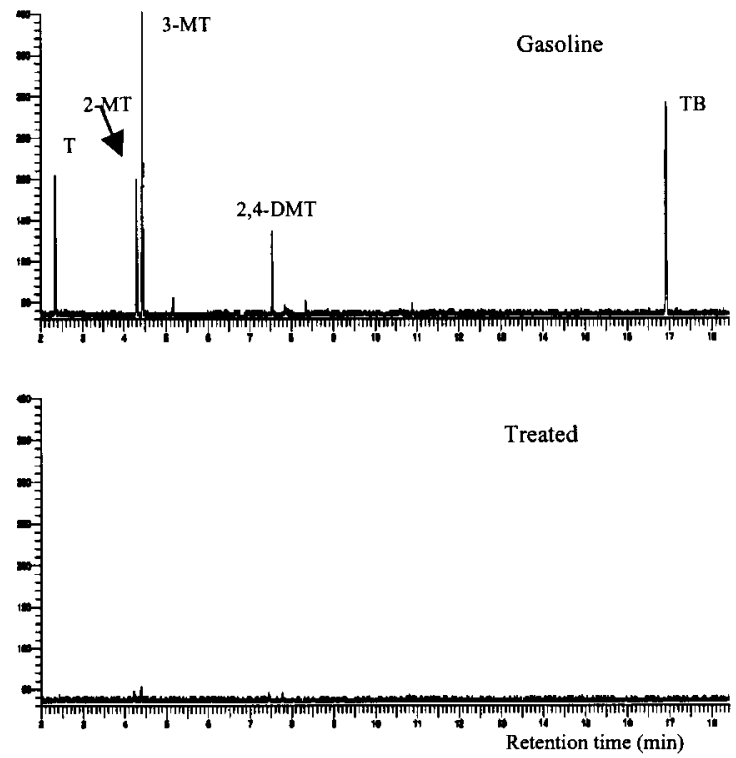

Figure 2. GC-FPD chromatograms of gasoline and treated gasoline 


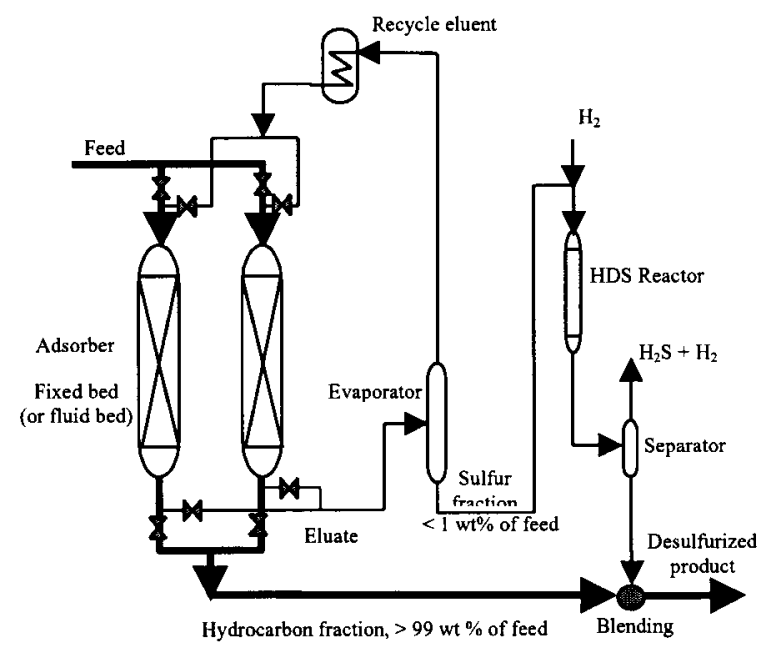

Figure 3. The proposed adsorption process for ultra-deep desulfurization 